\title{
História, ciência e linguagem: a agência material e o impasse realismo versus relativismo
}

\author{
History, science, and language: material agency \\ and the realism versus relativism impasse
}

\author{
Fernanda Schiavo Nogueira \\ Doutoranda, Universidade Federal de Minas Gerais. \\ fernandaschiavonogueira@gmail.com
}

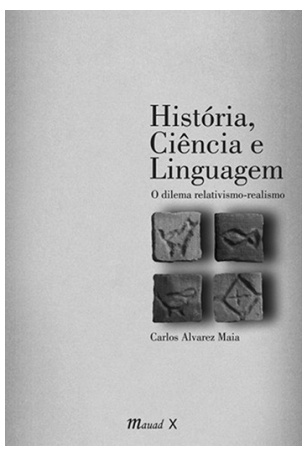

MAIA, Carlos Alvarez. História, ciência e linguagem: o dilema relativismo-realismo. Rio de Janeiro: Mauad X. 2015. 184p.
To mais recente livro do historiador da ciência Carlos Alvarez 1 Maia, História, ciência e linguagem, publicado em 2015, pela editora Mauad X, podemos acompanhar como o autor, insatisfeito com as (pseudo)soluções dadas pelo realismo/relativismo, procura romper com a antiga polarização quando investiga a produção do conhecimento. Identificamos, como objetivo central da obra, a preocupação em compatibilizar a utilidade explicativa de cada uma das intepretações, antes incompatíveis, em uma mesma abordagem: o "neorrealismo", denominação dada para abordar o principal objeto de estudo das ciências, a noção de realidade. Para tanto, o autor redefine a atuação de eixos estruturadores do conhecimento, os três componentes com os quais escolheu intitular seu livro, ou seja, a história, a ciência e a linguagem, utilizando o conceito de agência material.

Chama atenção o fato de a obra avançar sobre uma tradicional lacuna constatada na produção historiográfica, seja nacional ou internacional: a ausência de maiores tentativas de analisar como história, ciência e linguagem estão intimamente relacionadas e operam conjuntamente na produção do conhecimento. Faltam investigações que evidenciem as articulações que ocorrem entre os três elementos: a maioria dos estudos ora privilegia apenas dois componentes, ora enfatiza demasiadamente a importância de um. Para dar novo enquadramento à questão ainda não interpretada satisfatoriamente, Maia adota a perspectiva teórico-pragmática, estruturando as interpretações feitas sobre a tríade em torno do conceito de agência material. Assim, o autor rompe com concepções idealistas que ainda fomentam a sobrevivência de mitos capazes de obscurecer nosso entendimento, como a mitologia positivista do realismo.

No livro, percorremos o trabalho minucioso do autor para caracterizar as repercussões desencadeadas pela desintegração do grande centro irradiador de certezas absolutas: a mitologia positivista do realismo. Compreendemos o processo pelo qual houve a dissolução 
do mito do objetivismo que pressupunha características imanentes do objeto, uma natureza inerente aos fenômenos que possibilitaria a descoberta das leis de funcionamento do mundo. A realidade não constitui mais uma essência autoevidente, dada por si, cuja existência independe do poder de criação humana. O conhecimento, acusado de não proporcionar a reprodução idêntica dos fenômenos, fica desacreditado na sua capacidade de desempenhar a finalidade que originalmente ocupava: duplicar a realidade.

Desde 1960, as mudanças intelectuais emergentes favoreceram o surgimento de movimentos reconhecidos como difusores do relativismo: o Programa Forte e o Linguistic Turn. Ambos não idealizam a realidade como manifestação objetiva, em que os fenômenos se apresentam em estado de natureza, independentes das definições criadas para os tornar compreendidos. Os eventos naturais e sociais ou o passado, corporificado nos documentos, são modelados pelo discurso, pela coerência interna do texto elaborado por cientistas ou historiadores para o convencimento dos seus pares e de seus leitores em potencial. Todavia, a valorização da linguagem foi tão superestimada pelos movimentos que acarretou a desconstrução do principal diferencial das formas de conhecimento, com pretensões realistas: a necessidade de o discurso estar ancorado no mundo supostamente real. Os atores humanos são projetados como os únicos responsáveis por determinar o que ocorre no mundo, independente do aval dos fenômenos. A realidade foi transformada em mero coadjuvante silencioso - invisível.

Os pontos de vista apresentados por Maia nos possibilitam articular instrumentos mais eficazes para superar a divisão realismo/relativismo, ao defender a criação de uma terceira via, isenta dos problemas corriqueiros das explicações polarizadas. As interpretações dadas pelo autor abrem nossos horizontes para novas possibilidades de compreensão dos principais pilares da produção de conhecimento, história, ciência e linguagem, articulados sobre o conceito de agência material.

A agência material ocorre quando os indivíduos aprendem, em sociedade, a distinguir quais referenciais disponibilizados pela linguagem poderão dar significação ao mundo onde vivem para conseguir interagir entre si e com os fenômenos que os rodeiam - o sujeito produz seus conhecimentos reagindo, respondendo e contrapondo-se ao meio natural ou social que o cerca. As agências materiais, contudo, não constituem meramente "interações", mas "intraações" estabelecidas entre homem e mundo. As partes envolvidas, quando interagem, são, simultaneamente, constituídas e transformadas em novos sujeitos e objetos.

O conceito de agência material nos permite entender a ciência como um conjunto de atividades capaz de remeter à categoria do "trabalho", procedimento, por excelência, do qual decorre a transformação da realidade. A ciência equivale a muito mais do que simplesmente um "saber", uma representação abstrata de teorias sobre o mundo: ela corresponde a um "fazer", desenvolvido para intervir, prever e controlar os fenômenos. A produção do conhecimento não estaria limitada, portanto, ao que compreendemos por "social", as decisões tomadas pelos agentes humanos, que arbitrariam, pelo uso da linguagem, como deveriam ser os comportamentos dos fenômenos.

Constatamos a necessidade de substituir a ideia de "social" pela de "pós-social", apta a dissolver as barreiras entre duas unidades consideradas autônomas - a sociedade e a natureza promovendo, sua integração em uma socionatureza. A socionatureza consiste em caracterizar 
o jogo societário como aquele que abrange as relações dos indivíduos entre si e com o meio em que estão inseridos, ou seja, os elementos sociais e naturais são tratados de maneira inclusiva por Maia (diferente do que ocorre com o que convencionalmente pensamos como "social").

Na obra, podemos avaliar a importância dada à participação da linguagem para toda e qualquer agência material ser efetivada. $\mathrm{O}$ autor chama atenção para que não reconheçamos a linguagem como uma correia de transmissão neutra, utilizada para comunicar as ideias criadas mentalmente sobre os fenômenos, sob o comando da razão. Ela constitui uma ação concreta na realidade, com a qual os falantes traduzem as significações apropriadas do mundo para produzir um acervo de referenciais capaz de orientar a sua atuação no próprio mundo. Os fenômenos são visualizados apenas se forem significativos, caso apresentem, antecipadamente, ressonância na linguagem praticada socialmente - o objeto, desde a primeira observação, surge inscrito no universo das classificações definidas pelas palavras. As palavras e os fenômenos não pertencem a duas ordens separadas, em que uma seria epistemologicamente prévia à outra e possuiria a capacidade de determinar o que aparece depois: ambos são formulados conjuntamente.

As reflexões desenvolvidas no livro contribuem para evidenciar a historicidade da produção do conhecimento, pois desconstroem a crença equivocada em entidades ontológicas: nada aparece em seu estado de nudez, despido das vestimentas criadas pelas palavras para sua definição. A realidade não existe em si, porque artefato elaborado historicamente por indivíduos capacitados pelo aprendizado social, a transformar em linguagem as informações colhidas na observação do mundo. O indivíduo constrói o fenômeno a ser conhecido quando decifra textualmente as significações que os referenciais da linguagem praticada lhe possibilitam detectar no mundo, segundo a comunidade de profissionais ao qual pertence, a sociedade e a época em que vive. Consideramos que todo esse novo panorama descortinado no livro compõe o que Maia denominou neorrealismo - o realismo histórico.

No tratamento inovador dado pelo autor a três eixos centrais do conhecimento, história, ciência e linguagem, podemos identificar, portanto, a construção de padrões de objetividade capazes de proporcionar parâmetros mais eficientes para analisar a constituição do principal tema de investigação das ciências, a noção de realidade. Por isso, o livro merece constar entre as leituras obrigatórias de todos os investigadores conscientes da necessidade de enfrentar um dos maiores desafios da atualidade: retratar o caráter histórico dos conhecimentos produzidos nas ciências naturais e humanas. 